\title{
Falia Expression Protecting Environmental Ecosystem in Barangka District
}

\author{
Saharul Hariyono 1 \\ Indonesian Language and Literature Education Department, Yogyakarta State University, \\ Indonesia
}

\begin{abstract}
Falia expression is a spoken language formulated in the linguistic and cultural facts supporting the community. This study aims to describe the falia expression of Muna society in Barangka district serves as a control to protect the forest, rivers, sea, flora, and fauna. The study used a qualitative approach with methods ecolinguistics. Source of research data is an oral speech in situations informant said that natural and candid as the primary data and research resources that have been published as secondary data. Time data collection was done in January 2019 until June 2019 in the region Barangka district. Data collection is conducted with involved participation techniques, observations, and interviews. Analysesare carried out during collection, reduction, presentation, and conclusions/verification. Data analysis is inductive-qualitative. The results showed that the role falia as of protecting the environment in Barangka district classified into five categories: First, falia as the protection control of forest; Second, falia as the protection control of river; Third, falia as the protection control of sea; Fourth, falia as the protection control of flora; Fifth, falia as the protection control of fauna. In general, falia expression classified in the imperative statements, either command or forbidden.
\end{abstract}

Keywords: Ecolinguistics , expression, falia, Muna Language, society Barangka.

\section{Introduction}

Language plays an important role in human life. According to the structural theory, language is a conventional arbitrary sign system that refers to the language spoken by people (de Saussure, 2011). The characteristic of the conventional agreement has signaled implicitly that the function of language is as a means of social communication adjusted in the convention (Soeparno, 2013). Therefore, language as an entity is used by people as the main tool of communication. Then, language is associated with a diachronic culture condition since people learn about culture almost entirely through language (Laksana, 2009). Language is an essential tool to maintain and acquire cultural values and may trigger cultural responses (Kato, 2018). Similar to language, culture is also being studied and bequeathed from generation to generation through deeds and communication (Juansa, 2019; Johnson \& Hinton, 2019; Parker, 2019). The relation between language and culture are inseparable, and they both complete each other (Evans, et. al., 2018; Gairola, 2019). Many aspects can be explored regarding the relationship between language and culture, one of them is taboo (Juansa, 2019; Yayuk, 2019). The subject is an overview of language as a social phenomenon 
that encodes world representation socially constructed (Alogali,,2018; Al-Rabaani \& Al-Aamri, 2017; Halliday \& Hasan, 1989).

Taboo is an oral language inherited from the older generation to the next generation. It is essentially a "ban" or "the forbidden". This phrase fundamentally instills the social values and norms that exist in society. The characteristic of taboo is dynamically demonstrated as a mechanism of social control that affects daily life (Allan \& Burridge, 2006). This matter can be seen from the research conducted by Mary Douglas about the culture of West Africans. The West Africans firmly separate the "sacred" things from the "profane" ones. Based on the separation, taboo happens if the profane (filthy) penetrate the sacred circle/territory. The overlap of the sacred and profane circles is caused by humans' behavior classified into distortion, ambiguity, and anomaly (Douglas, 1966). The characteristic of taboo is also found in the culture of Shona people in Zimbabwe. Taboo can encourage the continuity of a sustainable environment in highlighting the water, natural vegetation, and wild animals (Chemhuru \& Masaka, 2010).

In the context of Indonesian society, the taboo has different characteristics depending on each region. For instance, in the neighborhood of Sundanese people, the taboo is known as pamali which means a ban from karuhun (ancestors). Bajo people also address taboo as pamali (Basri et al., 2017; Uniawati, 2014). According to Minangkabau people, the taboo is called by the term pantang (Juansa, 2019). Kampar people call it by pantang larang (Nurmalina, 2015). Kutai Kartanegara society address taboo as tuhing (Riana, 2017). Meanwhile, in the neighborhood of Muna people, taboo is termed by o falia (Imbo, 2012; Mondolalo, 2015).

More interestingly, the falia expression which exists around Muna island is believed to occur only in that area and does not prevail in other areas, especially Indonesia. Falia is influenced by the creeds of animism and dynamism. Historically, along with the arrival of Islam in Muna during the reign of King Muna La Ode Abdul Rahman (Sangia Latugho) in the 1629-1665 period, falia expression is the integration between ancestral beliefs and Islamic teachings (Hadirman, 2018). Thus, it is not only limited as dhabu (taboo), but has been covered by ethics, norms, and cultivation of religious values in society. In producing daily interaction, Muna people always use the $o$ falia. Therefore, in the understanding of identity, more emphasis has been laid on the subjective carried by a group (Ahmed, 2016).

All this time, many studies discussing about falia in Muna society, Southeast Sulawesi, had been conducted in various aspects. As far as observed by the writer, falia was studied as the control mechanism in creating social order and harmony related to ethics, life motivation, and the need to appreciate the masterpiece of others (Basri, 2018). Falia has a role to shape the character of children in Muna society (Marafad \& Niampe, 2016). In terms of lexicon, the construction of falia is seen from the kaghati of kite as the traditional game of Muna society (Nirmalasari et al., 2019). Falia has a role to socialize the local wisdom values to the people of Southeast Sulawesi as an effort to prevesnt corruption (Jalil, 2018). Also, the katoba (Islamization ritual for children entering adolescence) is done by advising about falia in which is expected to be the buffer of the culture and conserve the natural resources (Fua, 2015). In terms of hermeneutics, falia is studied as local wisdom values to behave, keep the honor, self-respect, have a mutual love, protection, and be grateful (Mondolalo, 2015). In terms of religiosity studies, falia is meant to honor both parents, have a good manner, and keep the prayer times (Hardin et al., 2017). The local wisdom of falia is considered as the cultural capital in forming the generosity of Muna society (Taena et al., 2017).

In contrast to previous studies, the recent study focuses on studying falia expression of Muna society in Barangka district based on the viewpoint of ecology or ecolinguistics. Research about falia over the environmental aspects had been conducted by focusing on falia aspect about forest conservation. In the study, falia was described as a prohibition not to cut down big trees in which are then correlated with supernatural punishment in the form of diseases caused by the spirits 
inhabiting the trees (Taena et al., 2016). However, the difference of the recent study is in terms of the focus which aims to explore the falia expression in five categories as a control to protect the environment of the forest, river, sea, flora, and fauna, and to see how falia is related to the events (history) that ever happened in that place to enrich and expand the insight of knowledge.

The focus of the problem in the research is how the falia expression of Muna society in Barangka district serve as a control to protect the forest, river, sea, flora, and fauna? The aim to achieve is describing falia as a control to protect the environment of Muna society in Barangka district. The results are expected to be useful for educational matters, one of them is to be used as teaching materials of local wisdom (local content). In addition, the research results can also be used as a reference for the researchers who are interested in raising the matter of taboo. This study is also conducted because of some viewpoints: First, although a lot of studies had been conducted exploring falia, there still a lot of gaps to close, and one of them is conducting the research through ecolinguistics study with the ecological relevance; Second, the falia expression still leaves many hidden meanings inside.

\section{Theoretical Review}

\section{Taboo Language}

In history, the taboo word was discovered by Captain James Cook during his third voyage going around the world, in Tonga, Polynesia Island in 1777. Up to now, the basic concept of taboo as a "ban" remains unchanged (Gay \& Susanti, 2017; Laksana, 2009). The concept of taboo for Tonga people contains the elements of prohibition or avoidance which brings in punishment without any mediation and is believed by people beyond the senses of anxiety and shame (Ersoy \& Uysal, 2018; Gao, 2013; Wardhaugh, 2006).

Considering the types of folklore, taboo is categorized as a folk belief due to the elements of magic contained in taboo assumed by educated people as something simple or even silly and not logic, so that it couldn't be scientifically justified (Syahrir, 2017). With the increase of supernatural elements or law, people then start to believe that taboo comes from the power of Gods (Frazer, 1980). Once the word taboo spreads beyond his native land in Polynesia, the society and the researchers then try to relate it to the supernatural powers. One of them was Sigmund Freud who constructed the concept of taboo based on the theory of psychoanalysis in his book Totem and Taboo. Freud's concern on taboo was generated by the similarity of psychic products from his neurosis patients to the psychic products he found on the myths of primitive tribes (Freud, 2003). In general, taboo was inherited through the medium of speech described by the requirements consisting of signs or causes, and was expected to have a result.

The concepts of taboo will establish cause and effect in the operation described by Douglas as follow. First, first thing to see is that taboo contains the concept of sanctity and profanity. Second, to note also is that the sanctity and the profanity happen because of human behavior classified by Douglas as "distortion", "ambiguity", and "anomaly". The sanctity and the profanity occurring because of the distortion, ambiguity, and anomaly may cause danger and defilement (Douglas, 1966; Laksana, 2009). Taboo classification is generally divided into two, namely taboo action and taboo language. Taboo action is the taboo believed to wreak havoc for the person who did it, either directly or indirectly, while taboo language is in the form of lexeme, phrase, or sentence that should not be spoken directly both in oral and written (Sutarman, 2013). In relation to the base of taboo classification, the researcher will only discuss the concept of taboo actions 
which are believed to wreak havoc for Muna society in Barangka (based on the analysis of falia expression).

\section{Ecolinguistics}

Since the publication of the book The Ecology of Language: Language Science and National Development, Haugen's work, linguistic study in perspective of environment starts to be in demand. The relation between linguistic and environment is then called by ecolinguistics (Haugen, 1972). Language ecology refers to the social environment including geographic characteristics such as the topography of an area (beaches, valleys, lands, mountains), climate, and human basic economic needs such as flora, fauna, and mineral resources that can support human life. Thus, ecolinguistics tries to actualize a healthy environment by incorporating local ecological wisdoms into the language. The ecological awareness propagated in deep ecology could emerge from the changing beliefs and attitude towards the natural world (Khosravi et al., 2017)

Environment (ecology) in linguistics has a very significant role which is for the sustainability of language and to see local wisdoms including an ideology applied by a society with regard to environmental preservation (Mantiri \& Handayani, 2018; Nirmalasari, et al., 2019). Furthermore, in the study of ecolinguistics, it's described a dialectic relationship between environment, language and domination/control of language, and domination of human described by Bang and Door.

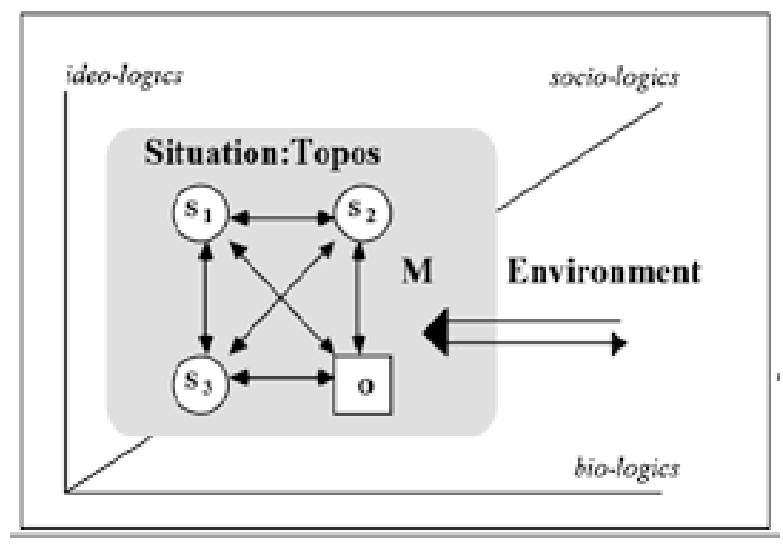

Figure 1. Model of Dimension Dialog by Bang \& Door (Lindø \& Bundsgaard, 2000)

In the chart, $\mathbf{S 1}$ is the author of the text, which is the speaker or the writer; $\mathbf{S 2}$ is the consumer of the text; $\mathbf{S 3}$ is the subject or anonymous category which is a sociocultural constituent; and $\mathbf{O}$ is the object referred in communication. Dialogue of the four constituents is represented by the sign " $\leftrightarrow$ " which occurs in Topos (space, place, and time) with the three-dimensional background of social praxis, namely the ideological, sociological, and biological dimensions. The other dimensions in the diagram which are out of the context but significantly contribute are: (a) the dimension of the ideo-logics which refers to cognitive mental system, ideology, individual and collective human psyche; (b) the dimension of the socio-logics which refers to the way humans are coordinating the interrelation to maintain the collectivity individually; (c) the dimension of the biologics which refers to the collectivity and the coexistence between humans and other creatures such as animals, plants, ground, microorganisms, etc. (Lindø \& Bundsgaard, 2000; Subiyanto, 2013; 
Yuniawan et al., 2017; Nirmalasari, et al., 2019). These three dimensions of social praxis are ecology or the environment of the language.

\section{Methodology}

This research is classified as qualitative research (Moleong, 2017). Through qualitative research, it is focused on study falia expression of Muna people based on the viewpoint of ecology or ecolinguistics. Considering that falia expression has been spread across Muna island, this research more focused in the area of Barangka district, West Muna Regency, Southeast Sulawesi. Barangka district has the width of area for about $33.09 \mathrm{~km} 2$ which consists of eight villages namely Sawerigadi, Barangka, Bungkolo, Lapolea, Walelei, Waulai, Wuna, and Lafinde. Thus, each village is represented by a single informant who knows about the falia expressions related to ecology. The selection of the research site is based on two considerations. First, the place is easy to reach because it's located on the central road of the city axis; Second, the natural resources are obviously natural, so that it can support finding the data about falia expression related to ecology. In addition, this study was conducted an ethnography method and in the frame of ecolinguistics. Ethnography seeks to narrate the tribes through the viewpoint of native point of view by displaying and representing the cultures of the society being studied, they are Muna people who live in Barangka. Meanwhile, ecolinguistics comprehends the subtleties of falia expression in the context of ecology. The data were collected from January 2019 until June 2019.

The source of research data consists of primary data and secondary data. The primary data were obtained through verbal utterances in the result of field observations and interviews with informants. Determination of the informants was purposive with the consideration that the informants are people's influential in village as stakeholder kamokulano liwu (traditional figure), imamuno desa (council/Sara employee). The informants are La Deensi (kamokulano liwu, 74 years old, Sawerigadi village); La Hamuda (imamuno desa, 80 years old, Barangka village); La Poaki (imamuno desa, 70 years old, Bungkolo village); La Umala (kamokulano liwu, 68 years old, Lapolea village); La Dasi (kamokulano liwu, 78 years old, Walelei village); La Ode Impi (imamuno desa, 75 years old, Waulai village); La Ode Matalagi (kamokulano liwu, 73 years old, Wuna village); Safarudin (yaro, 70 years old, Lafinde village). The secondary data were obtained from records or documents related to the issues studied including the results of previous studies that have been published as books, journals, papers, proceedings, and other relevant documents to support the primary data.

The data collection was done with: 1) participant observation, diffused directly in the activities of Muna people, 2) in-depth interview, expected to obtain valid data about the falia expression known by the informant, 3) study documentation and library, to enrich and broaden the insight of knowledge about the object being studied, the researcher examined, recorded, and studied the documents relevant to the object of the study and published, 4) made notes field, which records all the things that took place at the time the writer in the field, 5) made data record, an activity of classification data research. Analisis was done during collection, reduction, presentation, and conclusion/verification. Data analysis is inductive-qualitative.

\section{Findings and Discussion}

The research findings of falia taboo in Muna society of Barangka district were classified into five categories. Then, to clarify the elaboration of data, analysis of falia expressions in this 
study was described based on the explicit meanings and implicit meanings. The explicit meaning is what 's contained in falia expression interpreted by the user community as a ban of acts forbidden by the tradition and belief, while the implicit meaning is what's derived from a deep meaning contained or hidden in falia expression. The following are presented in table form.

\section{Table 1}

Falia Expressions Enviromental Ecosystem in Barangka District

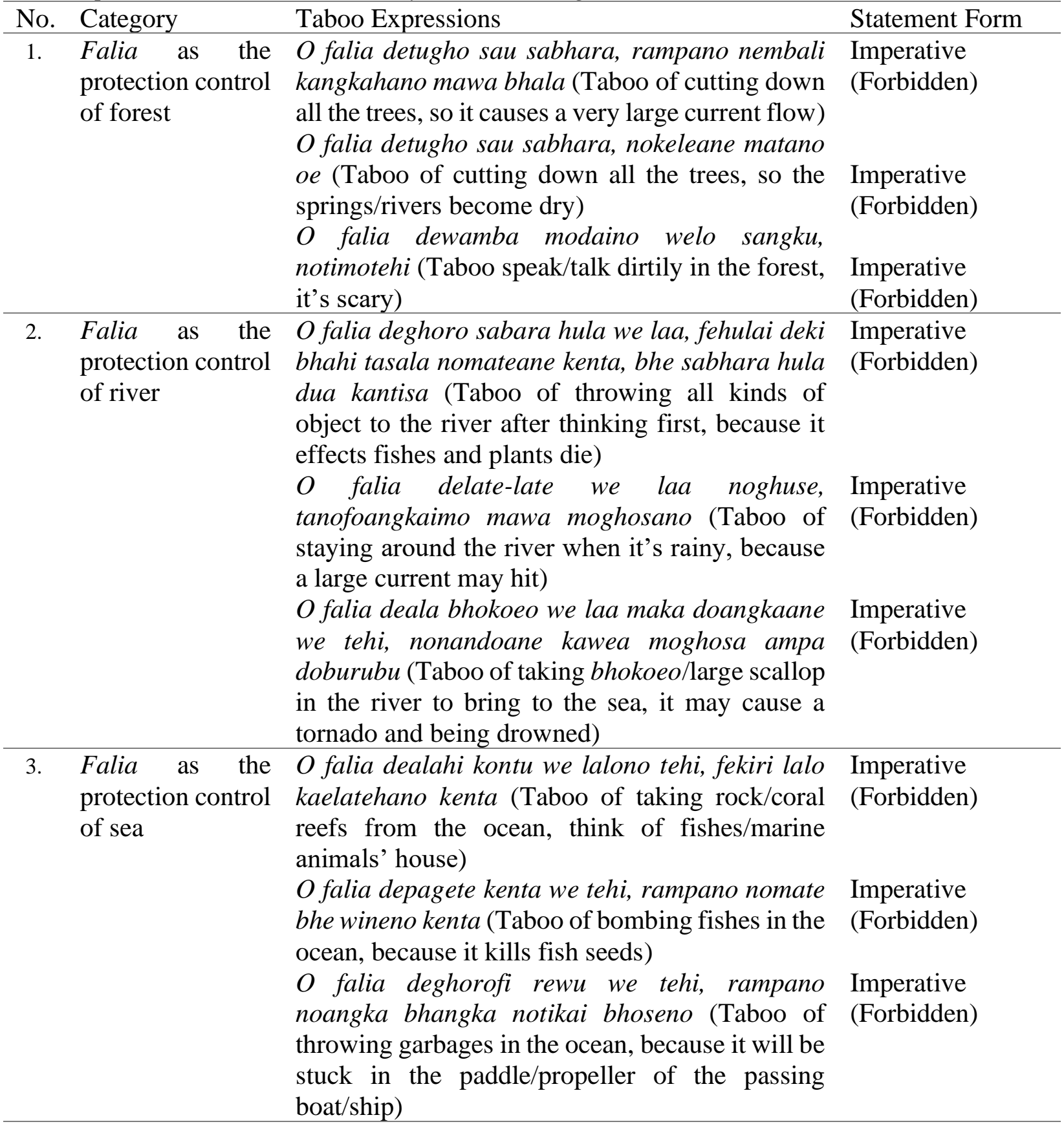

4. Falia as the O falia detobhe patu ne wiwino bhe fotuno laa, Imperative protection control mbali katahano wite noangka pangala bhalano (Forbidden) of flora (Taboo of cutting bamboo along the side and the 


\begin{tabular}{|c|c|c|c|}
\hline & & $\begin{array}{l}\text { upstream of the river, because it is the barrier of } \\
\text { the ground at the moment of flash floods) } \\
\text { O falia detugho kulidawa, beano nopandehaane } \\
\text { pamarinta (Taboo of cutting teak tree should be } \\
\text { known by the government) } \\
\text { O falia dengkora ne ghai, rampano ghai } \\
\text { nomaigho we fotuno mie (Taboo sit on the } \\
\text { coconuts because they come from humans' head) }\end{array}$ & $\begin{array}{l}\text { Imperative } \\
\text { (Forbidden) } \\
\text { Imperative } \\
\text { (Forbidden) }\end{array}$ \\
\hline \multirow{3}{*}{\multicolumn{2}{|c|}{$\begin{array}{l}\text { 5. Falia as the } \\
\text { protection control } \\
\text { of fauna }\end{array}$}} & $\begin{array}{l}\text { O falia depongko kadadi ane miina nakokahala, } \\
\text { rampano kafonandoono kakawasa (Taboo of } \\
\text { killing the innocent animal, for it is God's } \\
\text { creation) }\end{array}$ & $\begin{array}{l}\text { Imperative } \\
\text { (Forbidden) }\end{array}$ \\
\hline & & $\begin{array}{l}\text { O falia defokawu-kawu wewi, ane miina bhe } \\
\text { wewi oghule naomaamo mie (Taboo wipe out the } \\
\text { pigs, because if there is no pig, snakes will prey } \\
\text { on people) }\end{array}$ & $\begin{array}{l}\text { Imperative } \\
\text { (Forbidden) }\end{array}$ \\
\hline & & $\begin{array}{l}\text { O falia depongko ghule ane nando nobhala taghi } \\
\text { ibundo, bhahi tasala noghuloli anano (Taboo of } \\
\text { killing snakes when a wife is pregnant, do not let } \\
\text { her son born abnormally) }\end{array}$ & $\begin{array}{l}\text { Imperative } \\
\text { (Forbidden) }\end{array}$ \\
\hline
\end{tabular}

Note. Taboo expressions are not only show forbidden, but has been covered by ethics, norms, and cultivation of religious values in society.

\section{Discussion}

The administrative region of Barangka district belongs to the territory of Muna island and includes eight villages, namely Sawerigadi, Barangka, Bungkolo, Lapolea, Walelei, Waulai, Wuna, and Lafinde. Muna island is etymologically derived from the word "Wuna", one of the islands located at the tip of the southeast peninsula of Sulawesi island whose people are speaking Muna language in many purposes including communication (Mulawati, 2014). Muna Language is used in terms of katangari (suggestion), katudu (command), kafoguru (teaching), kaforato (announcement), kafenaghu (suggestion), and o falia (taboo) (Marafad \& Niampe, 2016). In the use of taboo, Muna people as a religious community believe the existence of a ban named falia. It is accepted as a tradition that still exists among Wuna (Muna) people wherever they are, and they keep implementing the philosophy of life Dopo pia-piara or to care and protect each other. In philosophy, humans are obligated to look after each other, including the environment around them. Falia becomes a verbal rule that can't be understood only by the form of language, but should also be addressed as a form of belief of their culture (Hardin et al., 2017). The assertion of falia is something conventional agreed by the chieftain and society which is applicable only in Muna island. The following is the location on the map in Barangka district. 


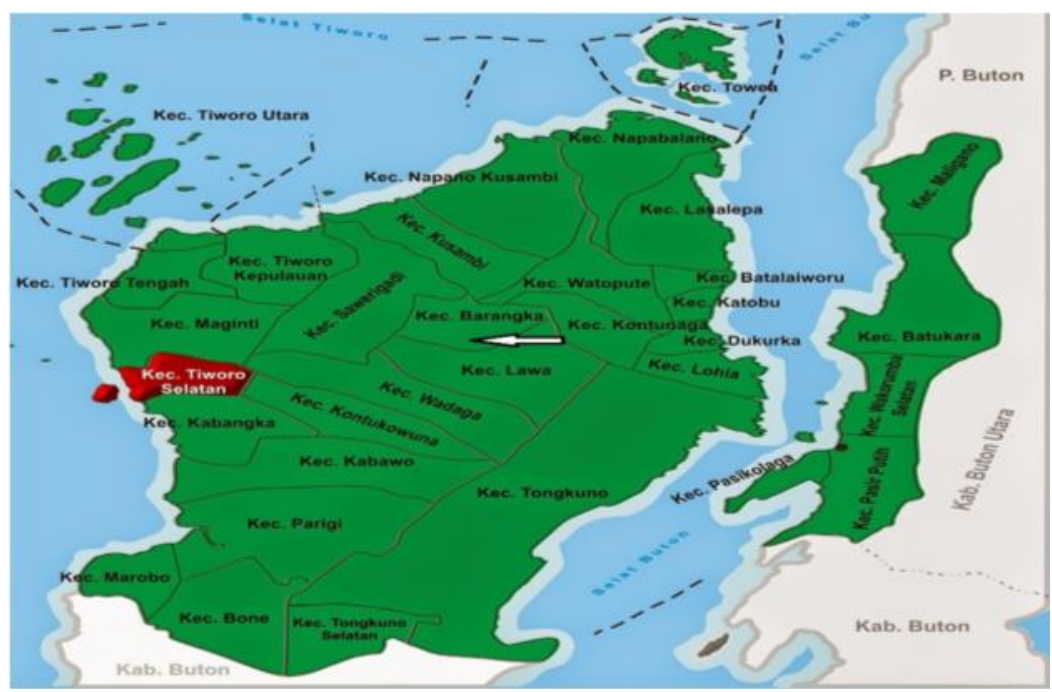

Figure 2. Map of Falia Speech Areas in Barangka District

\section{Falia as the Protection Control of Forest}

In regard to the social perspective of Muna people to behave, their members are always concerned with the neighborhood relations so that applies the norms: (1) norongga-noronggamo badha, sumanomo konorongga liwu (let the body crush, as long as the country remains upright); (2) norongga-noronggamo liwu, sumanomo konorongga adhati (let the country collapse, as long as the tradition remains upright); (3) norongga-noronggamo adhati, sumanomo konorongga agama (though the tradition's been wrecked, as long as the religion remains upright) (Niampe, 2013). This matter can be found in the lives of Muna people in Barangka district who used to look after each other in a unique meaning of the utterances related to the value and function of preserving the environment (ecology). Meanwhile, the phrases of taboo in the activities of protecting the forest environment are outlined as follow.

Taboo of cutting down all the trees, so it causes a very large current flow

The falia expression contains two statements:

1. The cause of tabor Taboo of cutting down the trees carelessly

2. The consequences of doing Causes a large current flow

This data was obtained from one of the imamuno desa (council/Sara employee) in Barangka village named La Hamuda (80 years old). Thus, he had a quite broad insight to know the falia expressions about forest. The informant added that he knew the taboo expression from whom were aged during his childhood as well as from his parents.

The falia expression contains two meanings which are explicit and implicit. The explicit meaning of this phrase is 'taboo of cutting down all the trees, so it causes a very large current flow'. Implicitly, the phrase reminds Muna people not to cut any trees. The cause is the very significant benefit of trees for humans and other living species. Tree is the foundation of caring for the ecosystem, supporting various aspects of life on earth. For instance, cleaning the dirty air particles, controlling temperature and humidity. More specifically, the share of falia is implied that trees can control the floods, landslides, and other natural disasters. It is based especially in Bungkolo village and Barangka village which have forests served as the lungs of the environment. People call them as bholo forest (dense forest) and kolitiri forest which contain many protected plants and trees such as the corpse flower, teak, mahogany, and others. There flow a lot of tributaries inside the forest, so that it is extremely prohibited to distract the habitat inside it, and the most emphasized thing is 
the prohibition of illegal logging. Thus, the existence of the forest and the falia expression are significantly correlated. If the trees in bholo and kolitiri forests are cut down, it will cause flash floods which could endanger the presence of people in Barangka district.

Then, the informant La Poaki (70 years old, imamuno desa, Bungkolo village) confirmed the existence of falia expression. Falia has surely been bequeathed through generations among Muna society. Even in practice, the spread of falia cannot be separated from the role of village imamu, which then is inherited through the teachings of katangarino imamu (the advice from sara council). Furthermore, the informant stated that the role of falia toward the forests is highly essential for the life sustainability of Muna society.

Taboo of cutting down all the trees, so the springs/rivers become dry

The falia expression contains two statements:

1. The cause of tabo Taboo of cutting down the trees carelessly

2. The consequences of doing itratrivers become dry

The overview of this falia expression cannot be released from the condition of forest in the area. Explicitly, this phrase is quite similar to the taboo described previously, but the emphasis is on the drought impact of cutting trees. Implicitly, the hidden meaning is that cutting trees does not only cause the flood, but also causes the lack of clean water sources. Based on the survey conducted, the informant and some people living there said that there was an appeal to the whole society not to cut any trees in the forest that had been the lungs of the environment. Therefore, the taboo is also correlated to maintain the forest ecosystems.

In other cases, it's tucked a taboo telling people not to act arbitrarily in the forest. It is told by the informant La Umala (68 years old) who has a prominent position in the midst of society as kamokula liwu (traditional figure) in Lapolea village. The existence of kamokulano liwu was formed before Muna island people know about kingdom. Their role is very significant in society, and they bind themselves in a "union".

Taboo speak/talk dirtily in the forest, it's scary

The falia expression contains two statements:

1. The cause of tab Taboo to speak/talk dirtily in the forest

2. The consequences of doing it It's scary

Explicitly, the falia concept tells people not to speak/talk dirtily in the forest. Implicitly, in speaking, people should protect the oral (language) without exception of protecting the nature, especially forests. Forests are overgrown with dense trees, plants, and the nests of wild animals. Muna society in Barangka district believe if someone says dirty words by raising the voice (shouting), it will bring himself or others into a danger. The danger comes when disturbing the forest dwellers like wild animals, because they will be hunted by these animals. The effects on nature will also interfere other animals whose hearing is better (sharper) than humans and typically used to hunt for meals, so it makes them more aggressive. Moreover, Muna people believe that there are certain places where spirits stay in the forest. If the trees are destroyed, the spirits will disturb the living people, and this situation can be sensed when the body feels nuere wulu or shivers (Taena et al., 2016). Based on the outstanding research about the protection of the ecosystems of Muna forest, at the time of Muna kingdom, land utilization was neatly arranged based on the tradition and with the permission of Sarano Wite or the Central Government (Niampe, 2013). Therefore, forests should never be destroyed in any way. 


\section{Falia as the Protection Control of River}

According to the data released by the General Directorate of Environmental Pollution and Damage Control of Indonesia in 2016, it's showed that most of the water quality in Indonesia is dominated by yellow water content which means being polluted. It does not occur only in Indonesia, but the countries throughout the world face the same problem. As in developed countries, the rivers are polluted by factories that emit the waste which then decomposes in the waterway so it drains the oxygen of water and creates an anaerobic condition (Peirce et al., 1997).

If water has been polluted, it will disrupt the ecosystem inside it like living fishes will die, and the spring can no longer be used by people. It is what should be noted that nature, particularly water, must be protected for the sustainability of the ecosystem. Generally, the river pollution often occurs in urban areas with high population density, and it happens without the awareness of people living around the areas. People who still have the sense of solidarity to protect the river are very few, and they are usually found only in rural areas/villages. It has fundamentally happened because people who live in rural areas still hold and adhere to the customary rules. Therefore, to prevent the environmental damages, especially rivers, Muna people in Barangka district apply the falia expression. They civilize the policy for the welfare and peace of humans, nature, and God. They believe that nature would be friend if humans want to preserve it. Otherwise, the nature would be wrath if humans behave arbitrarily.

Taboo of throwing all kinds of object to the river after thinking first, because it effects fishes and plants die

The falia expression contains two statements:

1. The cause of taboo $\rightarrow$ Taboo of throwing all kinds of object to the river

2. The consequences of doing $\quad$ Fishes and plants die

Explicitly, according to the data of the falia expression above, throwing items/objects arbitrarily to the river causes fishes and plants die. This data was obtained from the speech of La Ode Impi (75 years old, kamokulano liwu of Waulai village). Meanwhile, the implicit meaning of this phrase is meant that everyone who throws items/objects to the river should fehulai (think) first. According to the informant, it's as Muna people who will never forget the words of their ancestors. If the pogau (word) of falia which has been initiated as a prohibition is subsequently violated, it will cause balaa (disaster) for himself/herself and society. The most emphasized meaning of the data is the word fehulai. It means that someone must fehulai (think) before doing. The fehulai of this falia phrase is intended to clarify not to throw anything to the river, even though it's only a leave or tree branch, because it clogs the river currents that may lead to the flood.

In relation to the meaning of the falia expression, the informant La Dasi 78 years old, kamokulano liwu of Walelei village) said that falia expression usually has an expression confirming the nature and function of the language so the meaning spoken is more effectively conveyed and achieved. Thus, falia expression cannot be separated from the figurative meaning of language. Then, the informant La Dasi said a falia that people should stay away from the river when it's rainy.

Taboo of staying around the river when it's rainy, because a large current may hit

The falia expression contains two statements:

1. The cause of tabor Taboo of staying around the river when it's rainy

2. The consequences of doirg it A large current may hit

Explicitly, the data is advising people not to stay around the river when it's rainy because a large current may hit anytime. More implicitly, it is related to the previous data regarding the 
prohibition of throwing any object to the river which may cause the flow blocked. According to the informant, this taboo is more specifically intended for children who often bath in the river. When rain is falling heavily, the water flow in the river can be elevated and will automatically overflow. This case means nothing when the river flow is not obstructed, but if the flow is obstructed, it will cause the flood. Thus, this falia expression is especially advising the children. In addition, to intensify their awareness, it should be practically conducted through traditional approach, which is a local ritual named katoba (Islamization).

Katoba is an initiation ritual made for boys and girls around the age of 7-14 years old as the ceremony of being a muslim (Hadirman, 2018). In katoba ritual, the falia expression are frequently expressed as character education of love for nature and environment. The researcher exemplified it through the data falia mefodai omu matano oe (never break the springs), in hope that children in katoba will always remember the phrases expressed. Besides, it is also expected to become a cultural refuter for the sake of preserving the environment (Fua, 2015).

Based on the interview with people in Barangka district, when they were asked about the rules of falia, most of them were unable to explain the reason logically. They just said that it had become the rule/taboo which must be complied since a long time ago. The informant La Ode Matalagi (73 years old, kamokulano liwu of Wuna village) explained a falia which emphasizes if it's done, it may lead to disaster.

Taboo of taking bhokoeo/large scallop in the river to bring to the sea, it may cause a tornado and being drowned

The falia expression contains two statements:

1. The cause of taboo $\rightarrow$ Taboo of taking bhokoeo/large scallop in the river to bring to the sea

2. The consequences of doing It may cause a tornado and being drowned

Explicitly, this data is also advising people not to move the inhabitants of the riverbed (bhokoeo/large scallop) to the sea, because it would bring harm to the emergence of a tornado and because who brings the bhokeo by boat being drowned. Muna people believe that if falia is violated, there will happen a fatal condition for the subject and the local community as well. According to the informant, there happened a removal of the biota (bhokoeo) long time ago, so it made the Sangia (Creator) wrath, and reportedly, the subject was drowned swept away by the ocean waves. Implicitly, the falia expression indicates the taboo of moving any kind of inhabitants of the river biota to the sea, especially the scallops. In fact, there also a lot of scallops that only live in the sea (seashells), the fear is the mixing of the two types of shells which will affect the destruction or death of these two species. As known that shells are biota which can provide benefits of ecosystem sustainability, and one of them is the control mechanism of purifying the river and seawater between the two types of shells.

\section{Falia as the Protection Control of Sea}

Barangka district is strategically very far from the beach or sea. Most of the beach areas are out of West Muna territory, or by grouping is inside Muna Regency. Based on an interview with one of the informants named Safarudin (70 years old, yaro of Lafinde village), he said that although the majority of livelihoods of Muna people in Barangka are farming, they go with the sail to support the fulfillment of their needs in order to improve the standard of their family life. Furthermore, he stated that falia expression cannot also be separated from the marine environment. This informant's knowledge was based on his experience as the headman. For Muna people, someone who has 
served as the headman of the village is called by the name yaro. Here are the falia expression described by Safarudin as the protection control of the sea.

Taboo of taking rock/coral reefs from the ocean, think of fishes/marine animals' house The falia expression contains two statements

1. The cause of tabor Taboo of taking rock/coral reefs from the ocean

2. The consequences of doing it Think of fishes/marine animals' house

Explicitly, this falia expression suggests Muna people not to take rock/coral reefs from the ocean, because the object is a house for fishes/marine animals. Implicitly, the taboo phrase is intended for people to protect the ecosystem of marine life. The hidden meaning behind it is the meaning of the word fekiri lalo to indicate the state of a person to think or consider deeply about what to do. Furthermore, by studying the implied meaning of fekiri lalo, it is an appeal for people to keep thinking and considering deeply not to take or destroy the reefs. Occasionally, the meaning of fekiri lalo is expressed by a chieftain in Barangka by the words fekiri-fekiri deki lalomu to advise people to think before doing something. Thus, the taboo phrase above is correlated with the chain picture of marine ecosystem that if it's destroyed by human activity itself, the marine life will be diminished that impacts to humans as well. The informant La Deensi (74 years old) is kamokulano liwu from Sawerigadi village provide more detail about this taboo expression for keeping the sea, especially the survival of fish biota.

Taboo of bombing fishes in the ocean, because it kills fish seeds

The falia expression contains two statements

1. The cause of taboo Taboo of bombing fishes in the ocean

2. The consequences of doing It kills fish seeds

Explicitly, the data spoken by the informants prohibits bombing fishes in the ocean because it makes the seeds of fishes dead. Implicitly, the taboo phrase tells the coastal communities and fishermen not to catch fishes using the explosives (bomb) because it makes the seeds of fishes dead and the coral reefs damaged. Coral reefs take decades for the process of natural repair. The information resource of the researcher was obtained from the General Directorate of Marine and Fisheries Resources Control who states that the use of one fish bomb could blow up about 50 square meters of coral reef area (Ishak \& Fatimah, 2019). Thus, Muna people keep telling everyone to catch fishes using environmentally-friendly fishing gear. The various means of environmentallyfriendly fishing gear recommended are like traditional boat with a paddle drive (bhose), fishing gear, and tassi nets (Hamzah et al., 2019). By these actions, the expectation of aquamarine sustainability is kept awake. In addition, the informant La Deensi added the falia expression expected not to pollute the marine environment.

Taboo of throwing garbages in the ocean, because it will be stuck in the paddle/propeller of the passing boat/ship

The falia expression contains two statements:

1. The cause of tabor Taboo of throwing garbages in the ocean

2. The consequences of doing $\rightarrow \quad$ It will be stuck in the paddle/propeller of the passing boat/ship

Explicitly, this falia expression indicates the prohibition of throwing garbages in the ocean, because it will be stuck in the paddle/propeller of the passing boat/ship. Implicitly, the taboo phrase advises anyone, without any exception for the fishermen, not to throw garbages either the biodegradable or the non-biodegradable into the ocean. When it's done, however, a lot of impacts occur such as disrupting the shipping that makes the ship sunken/drowned, or even reducing 
amount of the fishes in the water. Moreover, it worsens the existence of fishes and marine animals which object to the sea polluted by garbages.

The ancestors of Muna society raises the taboo correlated with the existence of mythological creatures in the seabed named embu or giant octopus which often drags the ships to sink (Taena et al., 2017). Then, the taboo phrase described above is, "o falia debhose bhe deghoro sabhara hula we undalo nofogintaane embu," (taboo of throwing any objects when sailing in the ocean, because it would be dragged by the giant octopus). The most emphasized meaning in the taboo phrase is teaching people not to throw any garbages in the ocean because it can pollute the sea that leads to the damage of the marine ecosystem.

The desire of doing exploitation which is oftentimes committed by people against nature without balancing the rescue and recovery is very unfortunate. Developing an awareness of oneself toward the ecosystem is still very low. Thus, to raise the awareness of the importance of protecting the environment should be started at an early age or the age of children. One of the ways is through the sayings of the ancestors with the phrases to boost the character education (Marafad \& Niampe, 2016). In this way, the collective consciousness will be constructed sequentially and systematically. Thus, the taboo phrases are as the representation of religious sanctity, ethics, morals, and manners to build the integrity of protecting the environment (Laksana, 2009; Nirmalasari, et al., 2019; Uniawati, 2014). Therefore, describing the falia taboo of Muna society in Barangka is always subject to the local wisdom philosophy of their daily life.

\section{Falia as the Protection Control of Flora}

The utilization of plants as a medium of symbolism is carried by Muna people in Barangka district to control the ecosystem of flora. In the understanding and tradition, which they have already implemented for a long time, the flora is always treated by them the same as they treat humans because flora is equal in God's eyes according to them, which has the same lives. Thus, in order to recognize these plants, Muna people will not be released from kasambuno wite ritual, a ritual on cultivation ceremony (Yanti et al., 2018). The tradition hints them not to be arbitrarily selective, and it can be seen in the following falia expression.

Taboo of cutting bamboo along the side and the upstream of the river, because it is the barrier of the ground at the moment of flash floods

The falia expression contains two statements:

1. The cause of tabor Taboo of cutting bamboo along the side and the upstream of river

2. The consequences of doing it It is the barrier of ground at the moment of flash floods

The source of this falia was obtained from the informant La Umala (68 years old). Explicitly, it's prohibiting Muna society in Barangka district to cut bamboo along the side and the upstream of the river because bamboo has the benefit of being able to withstand the ground at the moment of flash floods. Implicitly, the taboo is actually meant as an expectation for Muna people not to cut the bamboo because the side or the upstream of the river is prone to flooding and landslides. Bamboo is a very beneficial plant for conservation and water normalization. The function of bamboo is the capability of keeping the air clean as it produces $30 \%$ of oxygen more than any other tree. The land overgrown with bamboos is very stable and less susceptible to erosion. As for everyday use, according to the informant, people are allowed to cut the bamboo only $1 / 3$ of the total number of the stems in hope that the cutting marks will grow back and can be utilized for the following productions. 
According to the informant La Dasi (78 years old), in the preservation of flora ecosystem, the thing to be considered is the type of tree that becomes the icon of Muna region, which is kuli dawa tree (teak) that should not be cut carelessly. For Muna people in Barangka district, the teak tree has a long history for them. Teak or kuli dawa was known by Muna people since the area was colonized by the Dutch colonial government. Meanwhile, the teak forest served as a plant (cultural teak) was developed in 1911 (Azhar, 2007). Therefore, there is a taboo phrase to protect the teak tree.

Taboo of cutting teak tree should be known by the governmen

The falia expression contains two statements:

1. The cause of tabo Taboo of cutting teak tree

2. The consequences of doing it Should be known by the government

This falia expression is explicitly advising Muna people not to cut the teak arbitrarily without the consent/permission by the government. Implicitly, the falia expression is trying to advise people that if they want to cut down the teak tree, they should first ask permission to the related parties such as bhonto (the chieftain) and the government. Such condition, according to the informant, had been practiced during the Dutch colonial era. The teak plants were brought by the Dutch people to be replanted in their country. They did a massive violence at that time by implementing a forced planting system of VOC (Verenidge Oostindische Compagnie) to plant the teak trees in Java. At that time, the teak was functioned to build merchant ships, warships, and to be traded, so they released an ultimatum to be considered by people not to cut any trees except the teaks (Zamroni, 2014).

An oral tradition developed by Muna society in district Barangka said that the teak in the area came from the land of Java brought by the Dutch people because the seeds were brought by Paelangkuta when the kapitalao (warlord) was returning from assisting Jepara people to war against the England (Azhar, 2007). It's narrated that when planting the seeds of teak for the first time in one area of Muna which then was called Napabalano, Paelangkuta swear an oath (in Muna Language) "Aetisa kuli dawa ini so-hintumu mieno Wuna, so-rayatino ne Wuna ini. Laha-lahae sopokalalambughono hasilino kuli dawa ini suano so-faraluno Wuna ini, naerimba maka nalompona panaeghawa kasalamati." (I'm planting this teak for you Muna society. Those who do not take advantage of this teak for the benefit of Muna society, sooner or later, he won't be safe). Therefore, for this reason, Muna society are very cautious in cutting down the trees. (Taena et al., 2016).

The informant La Dasi (78 years old) added that in the public life of Muna region, people are very concerned with the herbs that become their staple foods such as corn (kahitela), cassava (mafusau), yam (kolope), and any other plants, because they are believed to come from the human body. Thus, consumpting those staples should only be as needed and without any redundancy. Therefore, there emerges a taboo phrase in hope that people won't be mansawi (redundant) to food and always remember that it originally comes from human.

Taboo sit on the coconuts because they come from humans' head

The falia expression contains two statements:

1. The cause of tabor Taboo sit on the coconuts

2. The consequences of doing it The coconuts come from humans' head

Explicitly, the taboo phrase above indicates a prohibition for Muna people in Barangka to sit on the coconuts. The base of the taboo was understood by the informant as coconut trees came from a part of human body (head). Implicitly, the taboo statement teaches people to appreciate each other that plant is also a living creation of God. Based on the information resources from local 
community, this falia evolved from the ancient story about the intricacies of plants (tula-tulano kanandono ghoti) that came from the body of a boy. The story told about a boy whining to join his father for farming in Muna forest. Suddenly, the father cut down a shade tree and then hit the child. That's when the father heard a mysterious whisper from Sangia or Sanghiyang (something feared) to split the child's body into four pieces, and then implanted at the four corners of the cardinal directions. Furthermore, the body grew into some varieties of plants such as coconut (human's head), cassava (human's hands), sweet potato (human body), yam (human's legs). The falia of sitting on the coconuts, according to the informant, can be proven from the shape of coconut which resembles a human's head and has three holes resembling a pair of eyes and a mouth. In addition, it can be proven by the fall of a coconut that never hits people even when he/she is under the coconut tree. It is understood that a coconut realizes its friendship with humans and the similarity of the genes (human).

Another version of the intricacies of the plants came from the historical story of the first kite in the world during the days of Epi-Paleolithic (Mesolithic Period), which is kaghati whose manufacturing materials are very natural (plants) and also believed to come from the parts of the human body (Febriany et al., 2017). This story began from the chieftain La Pasindaidaino who had a wife named Wa Ntiwose and a boy named La Ghane. When Wa Ntiwose, who was pregnant for her second child, was craving foods that did not contain any blood. As a chieftain, La Pasindaidaino asked for the enlightenment to the Creator by the way of the hermitage. During the hermitage, he was inspired to sacrifice his son La Ghane by splitting his body into four pieces and then burying them in the four corners of the forest area in exchange for getting the staple food craved by his wife (Sifatu, 2016).

\section{Falia as the Protection Control of Fauna}

Fauna comes from the Latin which means animal nature. If the areas of animal habitat are destroyed, it will cause the interference of the balance of nature that affects the lives of the animals and other living things. The concern of Muna people in Barangka district toward the animal habitats can also be seen in the phrases of their traditional taboo. The following is a taboo related to the protection control of the fauna.

Taboo of killing the innocent animal, for it is God's creation

The falia expression contains two statements

1. The cause of tabor Taboo of killing the innocent animal

2. The consequences of doing it It God's creation

This taboo phrase was obtained from the informant La Hamuda (80 years old). Explicitly, this taboo phrase is telling Muna people not to kill animals arbitrarily because these animals are God's creation. Implicitly, this taboo gives advice to preserve the endangered animals that begin to disappear from their natural habitat. For instance, the animals referred by the falia are such as deer, kadue (anoa), manu kaampo (partridge), sapi bholo (forest cow), whose natural habitat is in Muna territory. The worse consequence, if it's violated, is that the existence of these animals may not be recognized anymore by new generations to come. The informant added that at the time when Muna region was still led by the kings of Muna, hunting of these animals was massively performed. Knowing that the animal species were decreasing, the King issued a command to reduce the hunting of the animals. To further promote the command, it was handled by the taboo phrase. 
In addition, there is also a falia that leads people not to kill an animal which becomes the agricultural pest; it's a pig. The following is a taboo related to the pigs told by Safarudin (70 years old).

Taboo wipe out the pigs, because if there is no pig, snakes will prey on people

The falia expression contains two statements:

1. The cause of tabor Taboo of wiping out the pigs

2. The consequences of doing it Snakes will prey on people

As known that this animal (pig) is a pest and a crop destroyer for farmers. However, the thing to consider in more detail is the explicit purpose of the phrase to abstain from killing or demolishing the pigs because it is associated with the intention that if the pig species decrease, the snakes will prey on people. Furthermore, in terms of the hidden (implicit) meaning, it is advising Muna people in Barangka not to kill the pigs. One of the words to clarify the prohibition meaning is the emphasis of the word defokawu-kawu (killing massively). In biological sciences, the concept of taboo has similarities with the explanation of the food chain. If the pigs are killed, the carnivorous animals such as snakes could no longer get any food, so they come to the villages to meet their needs preying on humans.

On the other hand, Safarudin added the information that there is a taboo that has a relation to the ban for not killing the snake when there is a pregnant woman or wife in the family. If it's done, the child will be born abnormally.

Taboo of killing snakes when a wife is pregnant, do not let her son born abnormally

The falia expression contains two statements:

1. The cause of taboo Taboo of killing snakes when a wife is pregnant

2. The consequences of doingit The child will be born abnormally

Explicitly, the taboo phrase is advising people in the family, especially the husband, not to kill the snake when his wife is being pregnant, because of the fear that the child born by his wife will become permanently disabled, for example, the child is born without arms or legs. The informant added that the taboo was frequently violated due to their lack of knowledge about the falia, so it happened that many children were born permanently disabled because of their behavior. Implicitly, the taboo hides another meaning. It is to explain that killing the snakes is the same as disrupting the environmental ecosystem. In Muna territory, particularly in the region of Barangka, their largest income is as farmers in the plantation of rice, corn, and peanuts. One of the fundamental problems faced by farmers is the crop failure due to the ferocity of the crop pests' attack such as pigs, mice, and birds. Therefore, without the presence of snakes, the welfare of the farmers will decrease as well, because one of the benefits of the snake's presence is preying on the crop pests.

In addition, according to the people who understand the meaning of falia, it cannot be released by the phenomenon of the story about La Ode Wuna who was bodied partially as a snake and another part as a human that inhabits Muna island. This figure was described as an imperfect but powerful human who had a tail like a snake (Schoorl, 2003; Sudarmika \& Handoko, 2007). As explained as well, La Ode Wuna's father was the King of Muna Island who had no children even it's highly wished. Finally, he vowed to get the child "even half of the snake," and then the vow was replied by God with the birth of La Ode Wuna becoming half of the snake (Riyanto, 2017). Therefore, people believe that the snake inhabiting Muna island is the incarnation of La Ode Wuna which is considered taboo to be killed. 


\section{Conclusion}

The classification of taboo for Muna society in Barangka district is the taboo action that is linguistically formulated in the form of imperative statements, either command or forbidden. The taboo has explicit and implicit meanings with the dominant structure. Based on the data analysis, it's found five categories of falia as the control mechanism, they are protecting the forest, river, sea, flora, and fauna. In addition, the falia expression provides an overview that it is an indigenous knowledge spread through oral speech. Although the falia expressions are undocumented in the books and only obtained orally delivered by the predecessors, these falia expressions are sincerely adhered to by Muna society in Barangka district in their everyday life. Therefore, this taboo phrase needs to be maintained and protected properly. The social life which now has entered the modern era needs the falia expression that will drive people to form a communal harmony. Thus, it is important to state that the use of wamba wuna (Muna Language) in communication is a form of participation to preserve the cultural wealth of a nation.

This article is still far from the word "perfect", because the object of research used only covers taboos related to protecting the environment, it is fitting to touch into other realms that can be studied such as through character education that can be used as cultural learning in schools. In addition, the implications of this research can open broad horizons to the community itself because many young people are beginning to rarely use their own Muna language along with the times. Since the 1990s the population in this village began to shift to Indonesian (the national language), so that more children and adolescents did not master their mother tongue, especially the expression falia. To the public (readers) can be a new literacy about the various taboo expressions, one of which is used as a function of protecting the environment. There will be pressure on future researchers by producing this falia expression through books (curriculum, textbooks) given the Muna language documentation is relatively low.

\section{Acknowledgment}

Further, thanks are delivered to the informants of Muna society in Barangka district, especially in the areas of Sawerigadi, Barangka, Bungkolo, Lapolea, Walelei, Waulai, Wuna, and Lafinde villages who have helped the process of data collection, and also to Mr. Nurhadi, the lecturer of Indonesian Language and Literature Education Department, Yogyakarta State University, who has already helped so much to validate and verify the data findings.

\section{References}

Ahmed, M. (2016). Ethnicity, identity and group vitality: A study of Burushos of Srinagar. Journal of Ethnic and Cultural Studies, 3(1), 1-10. https://doi.org/10.29333/ejecs/51

Al-Rabaani, A. H., \& Al-Aamri, I. H. (2017). The effect of using cartoons on developing Omani grade 4 students' awareness of water issues and their attitudes towards using them in teaching social studies. Journal of Social Studies Education Research, 8(1), 35-46.

Allan, K., \& Burridge, K. (2006). Forbidden words: Taboo and the censoring of language. Cambridge University Press.

Alogali, A. (2018). World Englishes: Changing the Paradigm of Linguistic Diversity in Global Academia. Research in Social Sciences and Technology, 3(1), 54-73. Retrieved from http://ressat.org/index.php/ressat/article/view/342 
Azhar, M. A. (2007). Kerusakan ekologis hutan jati di Kabupaten Muna: Potret pemujaan pendekatan Anthroposentris. Jurnal Ilmu Sosial Dan Ilmu Politik, 11(2), 153-286.

Basri, L. O. A. (2018). Tradisi falia sebagai mekanisme kontrol dalam menciptakan tertib dan harmoni sosial: Telaah terhadap tradisi falia masyarakat Muna di Sulawesi Tenggara. Acarya Pustaka, 5(2), 7-16.

Basri, L. O. A., Mudana, I. W., Habsah, W. O. S., Marhadi, A., Tarifu, L., Burhan, F., \& Janu, L. (2017). Pamali, Bajo's local wisdom in the conservation of marine resources. Asian Social Science, 13(12), 63-67.

Chemhuru, M., \& Masaka, D. (2010). Taboos as sources of Shona people's environmental ethics. Journal of Sustainable Development in Africa, 12(7), 121-133.

de Saussure, F. (2011). Course in general linguistics. New York, NY: Columbia University Press.

Douglas, M. (1966). Purity and danger: An analysis of the concepts of pollution and taboo. New York, NY: Routledge.

Ersoy, E., \& Uysal, R. (2018). Opinions of School Psychological Counselors on Giftedness and Gifted Students' Education. American Journal of Qualitative Research, 2(2), 120-142.

Evans, K., Russell, W., Furgione, B., \& Sheridan, A. (2018). "Won't You be my Neighbor?, Journal of Culture and Values in Education, 1(2), 1-22. Retrieved from http://cultureandvalues.org/index.php/JCV/article/view/7

Febriany, F., Aprilla, M., \& Wardani, L. K. (2017). Desain dan implementasi layang-layang pada interior komunitas Perlabaya. Seminar Nasional Seni Dan Desain: "Membangun Tradisi Inovasi Melalui Riset Berbasis Praktik Seni Dan Desain” FBS Unesa, 28 Oktober 2017, 218-225.

Frazer, S. J. G. (1980). Taboo and the perils of the soul. Boston, MA: The Macmillan Press.

Freud, S. (2003). Totem and taboo: Some points of agreement between the mental lives of savages and neurotics. New York, NY: Routledge.

Fua, J. L. (2015). Etnopedagogi katoba sebagai bentuk pendidikan karakter dan pendidikan lingkungan hidup pada etnis Muna. Pemikiran Islam, 1(1), 97-119.

Gao, C. (2013). A sociolinguistic study of english taboo language. Theory and Practice in Language Studies, 3(12), 2310-2314.

Gairola, R. (2019). Attitudes of secondary teacher trainees towards entrepreneurial education. Research in Educational Policy and Management, 1(1), 44-54. https://doi.org/10.46303/repam.01.01.4

Gay, M., \& Susanti, P. A. (2017). Taboo language within Ternate society: A study on its formation and reference. ISLLAC: Journal of Intensive Studies on Language, Literature, Art, and Culture, 1(1), 170-183.

Hadirman. (2018). Sejarah dan bahasa figuratif dalam tradisi katoba pada masyarakat Muna. Aqlam: Journal of Islam and Plurality, 2(1), 43-56.

Halliday, M. A. K., \& Hasan, R. (1989). Language, context, and text: Aspects of language in a social-semiotic perspective. London, UK: Oxford University Press.

Hamzah, A., Mukhtar, Abdi, \& Gafaruddin, A. (2019). Modernisasi alat tangkap pada nelayan Bajo: Sebuah studi pada nelayan suku Bajo di desa Latawe Kabupaten Muna Barat Provinsi Sulawesi Tenggara. Buletin Penelitian Sosial Ekonomi Pertanian Fakultas Pertanian Universitas Haluoleo, 21(1), 30-35.

Hardin, Hermina, S. \& Magara, I. (2017). Kajian religiusitas ungkapan falia (ungkapan pantanglarang) pada masyarakat etnik Muna di kabupaten Muna Barat. SEMNASBAHTERA, 1(1), 188-196.

Haugen, E. I. (1972). The ecology of language: Language science and national development. Stanford, CA: Standford University Press. 
Imbo, L. O. S. (2012). Kamus bahasa Indonesia -Muna: Wamba Malau do wamba-Wunaane. Unhalu Press.

Ishak, N., \& Fatimah, S. (2019). Pengawasan penangkapan ikan di zona ekonomi eksklusif Indonesia dalam membangun poros maritim Indonesia. Jurnal Wacana Hukum, 25(1), 5977.

Jalil, A. (2018). Socializing local wisdom values to the people of Southeast Sulawesi as an effort to prevent corruption. Asia Pasific Fraud Journal, 3(1), 51-57.

Johnson, C., \& Hinton, H. (2019). Toward a Brillant Diversity. Journal of Culture and Values in Education, 2(1), 56-70. Retrieved from http://cultureandvalues.org/index.php/JCV/article/view/27

Juansa, D. E. (2019). Expression of prohibition as a representatif of taboo in Baduy society. LITERA, 18(1), 36-56.

Kato, K. (2018). Cultural understandings of mental health: The role of language and ethnic identity. Journal of Ethnic and Cultural Studies, 5(1), 58-73. https://doi.org/10.29333/ejecs/102

Khosravi, G. D., Vengadasamy, R., \& Raihanah, M. M. (2017). Ecoethical significance of wilderness in pablo Neruda's selected poems. GEMA Online Journal of Language Studies, 17(3), 55-69.

Laksana, I. K. D. (2009). Tabu bahasa: Salah satu cara memahami kebudayaan Bali. Udayana University Press.

Lindø, A. V., \& Bundsgaard, J. (2000). Dialectical ecolinguistics: Three essays for the symposium 30 years of language and ecology in graz december 2000. University of Odense Research Group for Ecology, Language \& Ideology Nordisk Institut.

Mantiri, G., \& Handayani, T. (2018). Dampak ekologis penggunaan kalimat indikatif pada media massa online Papua: Tinjauan ekolinguistik kritis. Ranah: Jurnal Kajian Bahasa, 7(2), $146-163$.

Marafad, L. O. S., \& Niampe, L. (2016). The role of falia expression in forming the character of a child in ethnic Muna in Muna district, Southeast Sulawesi. International Journal of Linguistics, Literature, and Culture, 2(4), 131-139.

Moleong, L. J. (2017). Metodologi penelitian kualitatif (36th ed.). Indonesia: Remaja Rosda Karya.

Mondolalo, D. (2015). Kajian hermeneutik nilai-nilai kearifan lokal kata-kata falia (tabu) masyarakat Muna. Riksa Bahasa, 1(2), 170-176.

Mulawati. (2014). Aspek sosiologis nyanyian pengantar tidur rakyat Muna. Kandai, 10(2), 190202.

Niampe, L. (2013). Upacara kaago-ago dalam tradisi perladangan pada masyarakat Muna: kajian bentuk, fungsi dan makna. MUDRA, 28(2), 121-128.

Nirmalasari, Mbete, A. M., Simpen, I. W., \& Putra, A. A. P. (2019). Falia's ke-kaghati-an in Muna speech community from the ecolinguistic perspective. E-Journal of Linguistics, 13(2), 233241.

Nurmalina. (2015). Pantang larang dalam masyarakat Kampar dan relevansinya dengan pendidikan karakter. Jurnal Obsesi, 1(1), 27-35.

Parker, J. (2019). Second language learning and cultural identity. Journal Of Curriculum Studies Research, 1(1), 33-42. https://doi.org/10.46303/jcsr.01.01.3

Peirce, J. J., Weiner, R. F., \& Vesilind, P. A. (1997). Environmental pollution and control (4th ed.). Elsevier Science \& Technology Books.

Riana, D. R. (2017). Pemaknaan motif tabu dalam cerita rakyat di wilayah bekas Kerajaan Mulawarman, kerajaan Hindu tertua di Indonesia. Aksara, 29(2), 197-210. 
Riyanto, G. (2017). Bermain-main dengan kebenaran sejarah: Kontestasi kedudukan dan produksi sosial narasi awal mula. Antropologi Indonesia, 37(1), 1-16.

Schoorl, J. W. (2003). Masyarakat, sejarah, dan budaya Buton (1st ed.). Djambatan \& KITLVJakarta.

Sifatu, W. O. (2016). Manfaat kaghati roo kolope bagi masyarakat Muna sebelum Islam. Etnoreflika, 5(2), 157-162.

Soeparno. (2013). Dasar-dasar linguistik umum. Indonesia: Tiara Wacana.

Subiyanto, A. (2013). Ekolinguistik: Model analisis dan penerapannya. Humanika, 18(2), 1-9.

Sudarmika, G. M., \& Handoko, W. (2007). Kerajaan Sahulau: Melacak fragmen sejarah yang hilang. Kapata Arkeologi, 3(4), 50-73.

Sutarman. (2013). Tabu bahasa dan eufemisme (1 1 st ed.). Yuma Pustaka.

Syahrir, E. (2017). Ungkapan pantang larang masyarakat Melayu Belantik. Madah: Jurnal Bahasa Dan Sastra, 7(2), 237-250.

Taena, L., Laepe, A., Basri, L. O. A., Miliha, L., Lio, A., \& Suardika, I. K. (2017). Tradition of "falia" local wisdom as cultural capital in the formation of magnanimity of Muna society. Journal of Sustainable Development, 10(5), 217-224.

Taena, L., Sailan, Z., Nalefo, L., Basri, A., Laepe, A., Samsul, S., Helmina, S., Miliha, L. \&, \& Kuasa, W. (2016). The cultural tradition of "falia" in preserving forest by Munanese ethnic. Journal of Sustainable Development, 9(5), 200-2006.

Uniawati. (2014). Perahu dalam pamali orang Bajo: Tinjauan semiotika sosial Halliday. Jurnal Pendidikan Dan Kebudayaan, 20(4), 568-578.

Wardhaugh, R. (2006). An introduction to sociolinguistics (5th ed.). Blackwell Publishing.

Yanti, M., Basri, L. O. A., \& Suraya, R. S. (2018). Ritual kasambuno wite pada tradisi perladangan masyarakat Muna di desa Lupia kecamatan Kabangka kabupaten Muna. LISANI: Jurnal Kelisanan Sastra Dan Budaya, 1(1), 31-42.

Yayuk, R. (2019). Klasifikasi tabu pada masyarakat Banjar. Kandai, 15(1), 27-46.

Yuniawan, T., Rokhman, F., Rustono, R., \& Mardikantoro, H. B. (2017). The study of critical ecolinguistic in green discourse: Prospective eco-linguistic analysis. Jurnal Humaniora, 29(3), 291-300.

Zamroni, M. (2014). Jati Jawa kontribusi kayu jati bagi masyarakat Jawa. GELAR, 12(1), 58-70. 